\title{
Mapping the geography of choirs in Sweden
}

\author{
DOI: https://doi.org/110.30664/ar.111087
}

$\mathrm{T}$ he geography of choirs has seldom received attention in human geography and even less so in a Swedish context. This article analyses the geography of choirs in Sweden by focusing on choir members in the Church of Sweden. Sweden offers an interesting case of choral geography because of (1) the Church of Sweden's geographical presence, (2) the number of choir members, and (3) the role of religion in contemporary Swedish society. An intimation of the contemporary significance is that the Church of Sweden has 78,170 choir members in 2020 and is active in every municipality. The data consist of the Church of Sweden membership and choir members visualized in turn on maps. The qualitative analyses of the quantitative data reveal that there seem to be few youth-choir members in Sweden. There seem to be many children choir members in the larger cities but fewer in rural areas. The northern part of Sweden seems to have generally lower levels of choir members but higher membership in the Church of Sweden. Another finding is that high membership in the church does not necessarily mean a high number of choir memberships. For further studies, quantitative engagement with more datasets together with an engagement with post-secular theories is suggested.

\section{Introduction}

Choirs have made up a significant part of social and cultural life in Sweden for a long period. One of the earliest notes on choir music is in Uppsala cathedral's korsstadga (guidelines for the conduct of worship), which dates back to 1298 (Håkansson and
Sköldberg 2020: 11). Later in the early twentieth century, large organized mass choirs focused on themes such as nature and the Swedish nation. In the 1970 s smaller music communities were more common (Hedell 2009: 443). However, despite the long tradition of organized religious choirs such as in the Church of Sweden, there were also rich choral traditions, both secular and religious, in parts of Swedish society during the nineteenth and twentieth century. These activities took place mainly in labour unions, societies, popular movements and student choirs at all educational levels, along with other groups of individuals coming together in communal singing (Sparks 2000). In addition, Kia Hedell (2009: 418-19) argues that at the turn of the twentieth century, choir singing was also well established across genders, socioeconomic classes, ages, and singing abilities in Sweden. Hedell further argues that from the 1960 on, there has been a steady rate of choir participation (p. 415).

The largest contemporary choir organizer in Sweden is the Church of Sweden. An indication of its significance is given by the following: in 2020 there were 4,391 choirs and 78,170 choir members in the thirteen dioceses, and 1329 parishes in the Church of Sweden (Håkansson and Sköldberg 2020; 
Svenska Kyrkan 2021a). Even more interesting is that 97 per cent of the Swedish parishes have choir activities and those without are able to share choirs (Håkansson and Sköldberg 2020: 21). The implication is that geographically the Church of Sweden is a vital factor in cultural life and is represented in almost all parts of Sweden. A result of this is that both urban and rural municipalities have access to the same organization throughout Sweden. However, there are also other entities, such as the second-largest choir organization, the Swedish Choir Organization (Sveriges körförbund). It is estimated that before the Covid-19 pandemic started in 2019, around 600,000 individuals (approximately 6 per cent of the population in Sweden) sang in a choir (Runevad Kjellmer 2021). As the Covid-19 pandemic resulted in so many choirs pausing all their activities, a debate about their importance in both social and cultural life emerged (Svahn 2020). This debate, made all the more evident during an ongoing pandemic, shows that choir participation is an important cultural and social phenomenon in contemporary Sweden.

Yet new forms of choirs do emerge, beyond the traditionally organized religious ones. Such tendencies are not new, as past choirs have always followed cultural trends and expressions in society such as the influences of jazz, gospel and pop/ rock (Sparks 2000). However, the existence of secular choirs in different forms has ensured that the new choirs have changed the meaning and expression of religious elements found in the activities of the traditional choir. Such choirs take many forms but some recent developments include appbased digital solutions, such as Joyvoice (2021), or digital/physical hybrid solutions, such as Piece of Me AB (2021). These mostly secular choirs focus on themes such as joy, health and well-being through choral singing. What seems to emerge is a multiplicity of religious and secular practices and beliefs, where the traditional boundaries between the secular and sacred are blurred (Beaumont and Eder 2019). Hence, these choirs are in line with the contemporary preoccupation with lifestyle issues in what are often called the world's most secularized countries (Kasselstrand 2015).

In this article, I will provide an exploratory and primarily descriptive mapping of the complex geographies of choirs. An indication of why choirs in the Church of Sweden are of interest for human geographical research is the intertwined aspects of (1) the lack of geographical research on choirs, discussed later in this article, (2) the Church of Sweden's geographical presence, (3) the high level of membership in choirs, and (4) the role of religion in contemporary Swedish society. To address these issues, datasets from the Church of Sweden on religious choirs and church membership are utilized. As I am interested in the urban and rural aspects, the Swedish Association of Local Authorities and Regions (Sveriges Kommuner och Regioner, henceforth SKR 2016) classification of municipalities is used to investigate the multifaceted geography of choirs. This method is used to answer the research question: What patterns, similarities, differences (for example in and between urban and rural municipalities), if any, can be gleaned from a qualitative analysis of choir member and membership data in the Church of Sweden?

What follows is a review of the themes and relevant previous research. Then the research question is presented in detail. Then, through a qualitative analysis of choropleth maps and descriptive statistics, the article aims to identify geographical patterns vis-à-vis population, choir members and church membership. I then provide a discussion of the methodological, 
empirical and theoretical relevance of this article. I also suggest further paths to follow in investigating the geographical study of choirs in Sweden and perhaps beyond.

\section{The geography of choirs}

Human geographers have had an extensive engagement with place, space and music over the last decades. In the later 1990s, researchers called for the examination of music, space, place, landscape, identity and locality (Smith 1994, 1997; Cohen 1995; Kong 1995; Leyshon et al. 1995). These researchers would influence geographical research and beyond by highlighting the 'generative relations between music, space, place, landscape, identity and locality' (Tweed and Watson 2018: 126). This focus has continued in more recent research (Connell and Gibson 2003; Waterman 2006; Duffy 2009). However, in the geography of religion, the focus on choirs is scant, although music in general has been focused on (Park 1994; Stump 2008; Ley and Tse 2013). Lily Kong (1995: 188) noted the importance of religion in the experience of music as it is influenced by 'factors such as the gender, class, ethnicity and religion of those involved'. These factors could be topics of interest when issues of religion are on the agenda; Kong (2010: 756) notes a revival of the geographical study of religion, which she points to with the question 'has the geographical study of religion finally arrived?'

As noted in the previous section, human geography in general has not engaged with choirs, their members and the location aspects of choirs in substantive ways. The few studies on the geography of choirs have mainly focused on music, identity and place. One such study is Kiera Mary Galway's Sounding Spaces (2017), where choral musicians were found to use music in the interactions between their individual and collective identities in Toronto, Canada. One of the key findings revealed that the participants attached meaning to specific churches and art centres. The study also highlighted the multiple and relational social spaces of community music, with spatial practices and discourses simultaneously competing in Toronto. Another notable study is by Daniel Cockayne (2019), which focuses on representation in the choral composition 'Considering Matthew Shepard', which tells the story of a gay man that was killed in 1998 in Laramie, USA. Cockayne discusses through a queer perspective the diminishing focus on representation in music geographies which have taken a 'practice and performance' turn. The author highlights the geographical insights of community choirs; 'amateur singing is a key site where music is connected to place-making, identity-building, feelings of belonging, and the production of inclusion and exclusion' (p. 475). Cockayne notes that community choirs are in general secular, in contrast to mostly sacral organizers, singers and repertoires (p. 472).

As a common feature of contemporary Christianity, Ursula Geisler (2010) identifies how choirs and their participants are not a widely studied topic in Sweden. Geisler and Karin Johansson (2019: 776) later argue that the study of choirs is complex and multifaceted, requiring varied approaches and theoretical perspectives. They argue that choirs are an important part of music culture and heritage in European countries, and as societal phenomena have impacts on issues regarding health, social benefits and democracy.

Spatial concepts have been more common in the social sciences since the 1980s (Brunn and Dodge 2017). The 'spatial turn' in the social sciences and humanities saw a rise in the engagement with the 
dialectics of the spatial and the social (Soja 1989; Warf and Arias 2008). Although geographical studies of choirs have been scant, examples of this focus can be found in health sciences (Theorell 2009; Lindström 2006), music studies (Hedell 2009; Lundblad 2019) and education/pedagogy (Hentschel 2017). In these, geographic concepts such as place and locality have been addressed, albeit with rudimentary theorizations of the dialectics of space, place and the social. Some studies have focused on issues on place identity in the light of both social and community cohesion (Haugland Balsnes 2009) or how the local landscape shapes the soundscapes of Christian hymns (Hawn 2015).

In theology, Andrew M. McCoy and John D. Witvliet (2015) have highlighted the potential of geographical perspectives. They argue that geographers are uniquely qualified for the analysis of 'regional differences, the spatial distribution patterns of singing practices, the interplay of immigration and singing practices, the relationship between congregational singing and spatial dimensions of human experience and identity' (pp. 2611-12). They put forward six reasons for this. The first reason is that choirs reflect and shape perceptions of the physical world and geopolitics. One example of this is identifying the church's place in missionary histories and the current environmental crisis. Also, hymns often incorporate spatial themes regarding 'where they [worshipping communities] are and where they are not' (p. 2612). Second, many choral practices are closely tied to geographical locations. This is evident as congregational songs often have a deep connection with local areas, which help to identify both hymns and practices with a particular area. Third, hymns often draw inspiration from elements of the physical world to invoke certain mental images. These could then in turn create and maintain religious imaginaries. Fourth, choirs can shape how individuals handle notions of immigration, diffusion, colonialism and globalization in their daily lives. This could involve, for example, persistence of singing traditions from an original location after migration. Fifth, choirs can influence the perception of what locations are 'central' and what is 'peripheral' in religious experience. This is exemplified by congregational singing often orienting individuals towards somewhere else, such as biblical locations, church leaders or regional worshipping hubs. Sixth, hymns can reveal patterns of appropriate responses to catastrophes through localized responses to different dangers and tragic events. This could be in the form of place-based relief efforts.

\section{Urban and rural aspects of choirs}

As previously noted, choirs are to be found in all of Sweden and engage an estimated 600,000 individuals. In this sense, choirs constitute an important part of Swedish cultural and social life in both urban and rural areas. Moreover, as noted by Ragnar Håkansson and Marita Sköldberg (2020), choirs are of huge significance especially in small communities, but also in larger cities. However, the rural population is increasingly represented as vulnerable subjects within research into economic and environmental resilience (Hudson 2006). Many rural locations host a variety of music enterprises despite these having to struggle economically to be viable industries (Gibson and Gordon 2016). For example, such enterprises consist of non-profit clubs, orchestras, ensembles, festivals and choirs. Community music, despite isolation and lack of critical population mass, enables rural individuals to develop viable social networks and utilize social capital (ibid.). Robert Putnam (1993), who discussed the 
role of choirs as sources of social capital, noted that in Italy, choral societies were one factor in the fostering of economic growth and local development as well as in greater civic involvement, not least since choral societies were a key aspect of the development of democracy in Italy, mainly through the horizontal bonds of social capital of the individual. Putnam famously noted, 'Communities don't have choral societies because they are wealthy; they are wealthy because they have choral societies - or more precisely, the traditions of engagement, trust and reciprocity that choral societies symbolize' (p. 106).

The relationship between urban and rural communities has been a matter of debate in recent years. Geographical location seems to matter in a Swedish setting, as urban spaces have been portrayed as drivers for economic and cultural growth (Stenbacka and Heldt Cassel 2020). In contrast, rural places seem to be problematic spaces with economic stagnation, decreasing population and fewer life opportunities. This was highlighted in a study by the Swedish Agency for Cultural Policy Analysis, which concluded that in terms of the accessibility of cultural events and activities, location is important (Myndigheten för kulturanalys 2019). In urban and densely populated areas, there is a wide variety and concentration of cultural entities such as performing arts societies and major museums, but participation in these activities is low. In rural municipalities, the most prominent cultural activity centres are libraries and adult-education associations (p. 11). One suggestion to mitigate the domination of merely a few bodies is to diversify these for increased local cultural life (p. 12). On the last note, the majority of religious communities such as the Church of Sweden actively collaborate in cultural activities with the ten largest adult-education associations all over Sweden.

\section{The post-secular world and choirs}

There seems to be a paradox in society that while individuals are supposedly becoming more and more secularized, at the same time religious expressions become more visible in society. The earlier contexts for religion and the religious seem to have changed (Taylor 2007). We seem to be in a situation where religion is redefined and reorganized (Beaumont and Eder 2019). This influences the way religious beliefs are expressed in society. What is emerging is a multiplicity of religious and secular beliefs, where the traditional boundaries are blurred (ibid.). Such post-secular perspectives originate from the critique by Jürgen Habermas (2008) of the paradigm of secularization. An attempt to list these by James A. Beckford (2012) gives six definitions: (1) secularization deniers and doubters, (2) building on the secular, (3) re-enchantment of culture, (4) public resurgence of religion, (5) politics, philosophy and theology, and (6) a plague on all your houses. Another list by Kristina Stoeckl and Dmitry Uzlaner (2018) reveals four types: sociological, normative, postmodern and theological. In short, all of these approaches acknowledge some kind of resurgence, a reorganization of religion in public life and the persistence of religious beliefs in societies.

Different questions arise concerning religion between urban and rural areas. Isabella Kasselstrand (2015: 288) showed that individuals in rural locations are significantly more likely to identify themselves as members of the Church of Sweden rather than of other religions or no religion. She also showed that most small villages have a church as the 'heart' of the local community. This may support the classic argument that the city is a secular realm with greater 
opportunities to live a secular life than rural areas (Beaumont and Eder 2019: 16). In previous post-secular studies, urban locations have been preferred as areas to study rather than rural locations (Molendijk et al. 2010; O’Mahony 2019). In the view of Justin Beaumont and Christopher Baker (2011), the 'post-secular city' is the site of resistance and adaptation to a globalized urban scene, where citizens in turn reterritorialize their subjective versions of space. The rural, on the other hand, is constructed as a realm of traditional religions (Beaumont and Eder 2019: 16). However, this distinction between urban and rural post-secularities has not received exhaustive treatment (Jones and Heley 2016; Gao et al. 2018); Beaumont and Klaus Eder (2019: 17) denote post-secular societies as 'a society where secular and non-secular principles - beyond others - circulate simultaneously through social relations'. Moreover, as regards choirs, there have only been a few engagements with the post-secular, such as Jonathan Arnold's account of sacred music in secular society and Céline Grünhagen's focus on hymns in hospital environments (Arnold 2019; Grünhagen 2012).

\section{Why a geographical investigation of choirs?}

From the discussion above it is evident that choirs are a significant part of the Swedish cultural landscape as well as of everyday life in both urban and rural contexts. The lack of interest in the geography of choirs in the discipline is surprising, as there seems to be a connection between choirs and the interlocking questions of identity, social capital and the meaning of place and spaces. Given that choir activities have generally been considered a religious activity, it is even more surprising that in religious geography choirs are an under-researched topic. Moreover, it is doubly ironic that even in music geography choirs have not received due attention. The present article tries to redress the lack of focus on choirs by conducting a first exploratory mapping of their geography. To this end, I focus on the following research question: what patterns, similarities, differences (for example within and between urban and rural municipalities), if any, can be gleaned from a qualitative analysis of choir member and membership data in the Church of Sweden?

\section{Mapping choirs}

In mapping choir members, the first step is to make sense of the data (Dodge 2015: 289). The process of mapping simplifies abstract reality into something more understandable, with fundamental choices about what and what not to reveal (p. 296). As a first step, choropleth maps were produced by means of the GIS programme Arcmap. Choropleth maps visualize and display data and the corresponding proportional symbols of the data (Chun 2017). In this article, the borders of the choropleth maps are to be understood as a visualization of the data and not a representation of the actual land surfaces, or national or administrative borders. This method does not focus on producing statistically significant results. Instead, it relies on visual and qualitative analyses of spatial and quantitative data. The visualization in itself is treated as a form of analysis as the spatial data are interpreted in a qualitative way (Pavlovskaya 2009). Then, by reflexive analysis the different data sources can yield a better understanding of cartographic representations of the socio-political reflections of the phenomena (Knigge and Cope 2009). My intention here is to explore map patterns, similarities and differences within and between urban and rural municipalities to reveal insights into the geography of choirs in Sweden through qualitative interpretations of quantitative data. 
The datasets used for analysis are official and openly available from the Church of Sweden for the year 2020 (Svenska kyrkan 2021a). ${ }^{1}$ The Church of Sweden was selected as it represents an interesting spatial case in that, as one organization, it is represented in all areas in Sweden. It is also the largest choir organizer in Sweden, with 4391 choirs and 78,170 choir members in 2020. One potential dataset that might have been used was a survey of the Swedish Choir Organization by Håkansson and Sköldberg (2020), where 97 per cent of the choirs in the Church of Sweden participated, revealing the type of choir, repertoire, genre and other details. However, it is presented on the level of the dioceses, which yields visualizations too broad to be useful in this article.

Two datasets were used in the production of the maps and subsequent analysis. The first dataset contains choirs membership for each municipality in Sweden for the year 2020. ${ }^{2}$ To provide a more nuanced image of the geography of choirs in the Church of Sweden, I have relied on the three categories - adults, youth and children - to map different age groups. The age groups included in these categories are decided by each parish, which results in a non-uniform definition. However, these categories were used in the analysis as they are collected and maintained in the official statistics. Displaying the data with choirs

1 These data are openly available from the Church of Sweden (Svenska kyrkan 2021a). I will provide the dataset upon request.

2 Forshaga and Munkfors municipalities in the Värmland County contain one parish, Forshaga-Munkfors församling. In this article, the numbers of choir members, the members in the Church of Sweden and the spatial areas of these municipalities are merged and linked to Munkfors (municipality code 1762). and its members by per mille of population enables a clear mapping and visualization of municipalities with a small population in the choropleth maps. The second dataset contains the members in the Church of Sweden for the year 2020 by municipality. Before the year 2000, the Church of Sweden was a state church, and one automatically became a member in the Church of Sweden at the time of birth (Svenska kyrkan 2021b). However, since the separation of state and church in the year 2000, individuals need to sign up actively. A member can be of any age and pay a fee through the tax system, which finances the Church of Sweden's activities such as choirs. In relation to choir membership, there is in most cases no requirement to be a member in the Church of Sweden to participate in activities. This is, however, a debated issue in some parishes (Söderberg 2018).

As the urban and rural dimension is of interest, this article relies on the municipality classification provided by SKR (2016) which is a well-established classification of urban and rural municipalities (p. 8). This classification is developed by the Swedish Association of Local Authorities and Regions, which is an employers' organization that represents all local government. It contains three main groups $(\mathrm{A}-\mathrm{C})$ with nine subgroups, with classifications based on population size, proximity to urban and regional centres and commuting patterns. In this article, $\mathrm{A}-\mathrm{C}$ will be used (see Table 1); the subgroups will not be considered as they focus mostly on commuting patterns, which is not of interest in this article. This classification is used to reveal and to identify patterns, similarities and differences in the urban-rural dimension.

In the choropleth maps, the scale distance for the classes is based on natural breaks (Jenks optimization method), which classifies data into optimal natural classes 
Table 1. Classification by SKR (2016)

\begin{tabular}{|c|c|c|c|}
\hline Code letter & Name & Classification & Number of municipalities \\
\hline A & $\begin{array}{l}\text { Metropolitan areas and } \\
\text { municipalities close to } \\
\text { metropolitan areas }\end{array}$ & $\begin{array}{l}\text { At least } 200,000 \text { inhab- } \\
\text { itants in the urban area }\end{array}$ & $\begin{array}{l}46 \text { ( } 3 \text { metropolitan } \\
\text { municipalities) }\end{array}$ \\
\hline B & $\begin{array}{l}\text { Larger cities and munici- } \\
\text { palities near larger cities }\end{array}$ & $\begin{array}{l}\text { At least } 40,000 \text { inhabit- } \\
\text { ants in the largest city }\end{array}$ & $\begin{array}{l}108 \text { ( } 21 \text { municipalities } \\
\text { with larger cities) }\end{array}$ \\
\hline C & $\begin{array}{l}\text { Smaller cities, urban areas } \\
\text { (tätort) and rural muni- } \\
\text { cipalities }\end{array}$ & $\begin{array}{l}\text { At least } 15,000 \text { and less } \\
\text { than } 40,000 \text { inhabitants } \\
\text { in the largest city }\end{array}$ & $\begin{array}{l}136 \text { (29 municipalities } \\
\text { with smaller cities) }\end{array}$ \\
\hline
\end{tabular}

(De Smith et al. 2018). The algorithm minimizes the average deviation from the class mean, but at the same time maximizes the differences from other groups of classes. It calculates this separately for every choropleth map, on the basis of three categories of choirs: adult, youth and children choirs and the membership in the Church of Sweden. The method visualizes the values for each category in the most comprehensible way for qualitative interpretation and not primarily for statistical analysis. Five classes were used as it was judged that these represented the data. The highest class was marked in green and the lowest class in red to aid in the qualitative analysis. Lastly, the three largest cities in Sweden Stockholm, Gothenburg and Malmö - are displayed in detail as they contain many small municipalities.

In a methodological sense, there has been a decline in interest lately in the use of cartographic representations in human geography (Dodge 2015: 291). However, mapping can present opportunities to reveal and evaluate quantitative data through qualitative analysis that otherwise would have been overlooked (Stuart Sinton and Huber 2007). However, maps portray 'a supra-nature view of reality: it is what space should look like and not what one would actually observe' (Dodge 2015: 295). Being sensitive to what maps represent and visualize is crucial. In addition, as critical cartographers have long noted, maps should 'be read not as mirrors of reality but as highly subjective representations of space' (p. 299). Lastly, as Lillian I. Larsen (2017: 323) notes, mapped surfaces are not hegemonically defined religious areas; a more mindful and qualitative interpretation of how worldviews and religion(s) are mapped is called for.

\section{Results}

The mapping results are grouped according to the three choir types, adults, youth and children, from the Church of Sweden. In these maps, noteworthy municipalities are pointed out. When a classification of an SKR (2016) municipality type is mentioned, the code letter is used (see Table 1). For each category, a table with the five municipalities with the highest number of choir members is also presented. Then follows a map of the percentage of membership of the Church of Sweden per municipality. In addition, tables with the five highest and lowest municipalities in terms of membership of the Church of Sweden are presented. The number displayed in brackets is the number of choir members per mille of inhabitants in that municipality or the percentage of members in the Church of Sweden. 


\section{Adult choirs}

In the Church of Sweden, there are 56,914 adult choir members. This is the largest choir type in terms of numbers. Ydre municipality has the highest number, with 30.66 members per mille of inhabitants (see Map 1 and Table 2). Seven out of 290 municipalities do not have any adult choir members. There are few adult choir members in type A. As for the area in and around the capital, there seem to be fewer choir members in the Stockholm municipality (3.09) than in the rest of the country. However, in the other bigger cities in Sweden, the numbers of choirs are comparable with those found in Gothenburg municipality (3.09) and Malmö (3.55). Many of the type B municipalities surrounding the largest cities Stockholm, Gothenburg and Malmö - have more adult choir members than in the country at large. In type $\mathrm{C}$, there seem to be fewer members in the north. This trend increases northwards, with some municipalities in the northern part of Sweden in group B with a low number of members. This includes the municipalities of Umeå (6.42) and Östersund (8.35). Two type C municipalities, Sorsele (28.25) and Malå (30.42), stand out in the north, with a high number of choir members.

In the southern half of Sweden, adult choirs appear to be more evenly distributed, for example in type B and $\mathrm{C}$ municipalities. However, some municipalities stand out, such as Växjö (2.2) and Kalmar (4.05), with fewer choirs compared to neighbouring municipalities. Båstad (15.64) is type C and has neighbouring type $\mathrm{B}$ municipalities with mostly fewer members. Two municipalities stand out with a high number of choir members: Grästorp (26.87) stands out since it is close to the type A municipality of Gothenburg (3.09); Ydre (30.66) is surrounded by places with a fairly high number of choir members.

\section{Youth choirs}

In terms of numbers, youth choirs are the smallest of the three categories. In total, there are 3.998 youth-choir members in Sweden and there is a maximum of 3.57 per mille of inhabitants (Lycksele) (see Map 2 and Table 3). Out of 290 municipalities, 129 do not have any youth-choir members. In general, youth choirs tend to have few members and be quite unevenly distributed in Sweden. A noticeable lack of youthchoir members is evident in the northern half of Sweden. This is apparent in both type $\mathrm{B}$ and $\mathrm{C}$ municipalities. However, one municipality stands out - Lycksele. It is surrounded by municipalities that have low choir membership levels and is also close to the larger city of Umeå (0.13). This trend is also apparent in major parts of the southern half of Sweden in both type B and C municipalities.

Table 2. The five municipalities sorted by the highest number of adult choir members per mille of inhabitants in the Church of Sweden in 2020

\begin{tabular}{|l|l|l|l|l|l|}
\hline Municipality & Adults & Youth & Children & $\begin{array}{l}\text { Members in the } \\
\text { Ch. of Sweden }\end{array}$ & Municipality type \\
\hline Ydre & 30.66 & 0.00 & 4.84 & $67 \%$ & C \\
\hline Malå & 30.42 & 0.00 & 0.00 & $75 \%$ & C \\
\hline Sorsele & 28.26 & 0.00 & 0.00 & $71 \%$ & C \\
\hline Grästorp & 26.87 & 0.00 & 3.02 & $77 \%$ & B \\
\hline Markaryd & 18.14 & 2.32 & 2.61 & $61 \%$ & C \\
\hline
\end{tabular}


Adult choir members in the Church of Sweden

per mille (2020)

- $0-4,38$

○ $4,39-7,69$

O $7,70-11,32$

11,33-18,14

18,15-30,66

\section{SKR (2017) Municipality types}
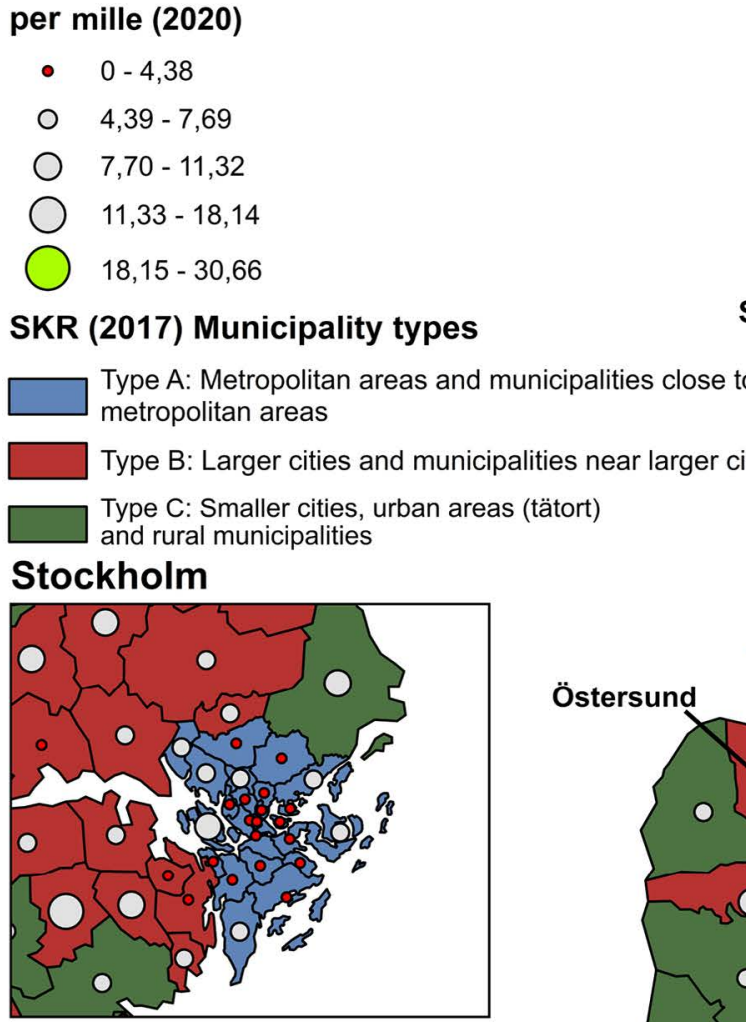

\section{Göteborg}

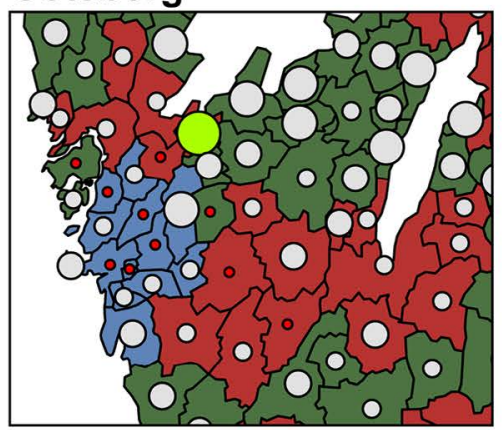

Malmö
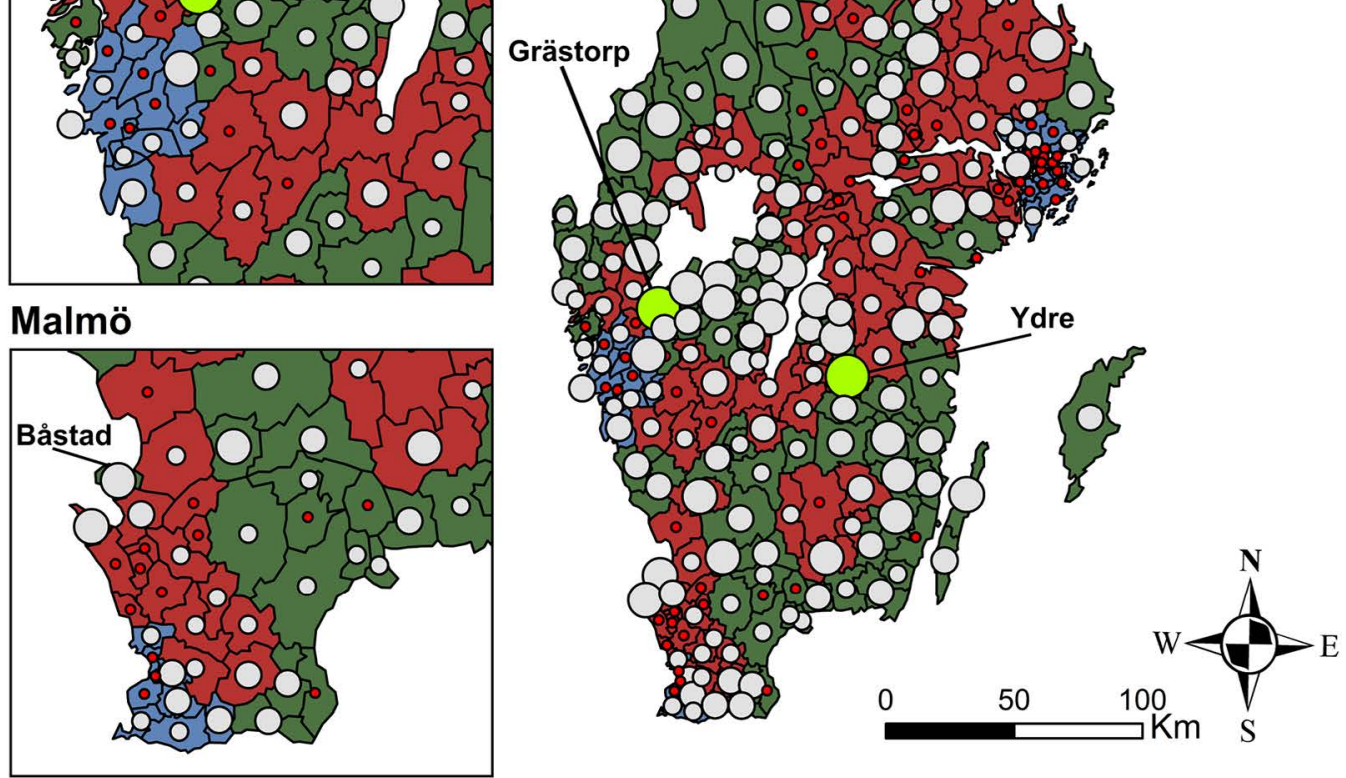

Map 1. Number of adult choir members in the Church of Sweden per municipality.

Map by the author. 
Table 3. The five municipalities sorted by the highest number of youth-choir members per mille of inhabitants in the Church of Sweden in 2020

\begin{tabular}{|l|l|l|l|l|l|}
\hline Municipality & Adults & Youth & Children & $\begin{array}{l}\text { Members in the } \\
\text { Ch. of Sweden }\end{array}$ & Municipality type \\
\hline Lycksele & 10.31 & 3.57 & 2.35 & $66 \%$ & C \\
\hline Ockelbo & 12.93 & 2.72 & 3.40 & $68 \%$ & B \\
\hline Avesta & 14.06 & 2.69 & 2.21 & $56 \%$ & C \\
\hline Götene & 16.24 & 2.50 & 4.10 & $67 \%$ & C \\
\hline Båstad & 15.65 & 2.40 & 6.75 & $65 \%$ & C \\
\hline
\end{tabular}

Table 4. The five municipalities sorted by the highest number of children choir members per mille of inhabitants in the Church of Sweden in 2020

\begin{tabular}{|l|l|l|l|l|l|}
\hline Municipality & Adults & Youth & Children & $\begin{array}{l}\text { Members in the } \\
\text { Ch. of Sweden }\end{array}$ & Municipality type \\
\hline Robertsfors & 15.57 & 0.00 & 15.13 & $70 \%$ & B \\
\hline Torsby & 8.50 & 1.56 & 11.10 & $77 \%$ & C \\
\hline Bräcke & 13.28 & 0.00 & 10.36 & $66 \%$ & B \\
Tranemo & 3.38 & 0.55 & 9.13 & $64 \%$ & B \\
\hline Tidaholm & 10.88 & 1.25 & 9.00 & $71 \%$ & C \\
\hline
\end{tabular}

In type $\mathrm{A}$, there is a concentration of youth-choir members. In Gothenburg (0.47) and Malmö (0.45), there is a somewhat higher concentration than in Stockholm. In addition, outside Gothenburg, there is a high concentration of members, mainly in type $B$, in particular in the municipalities of Båstad (2.4), Markaryd (2.31) and Älmhult (2.07). Outside Malmö in type B municipalities, there seem to be fewer youth-choir members.

In central Sweden the municipalities of Avesta (2.7), Ockelbo (2.72) and Rättvik (2.17) stand out in terms of youth-choir members. And there seems to be a concentration around the municipalities bordering Tidaholm (1.25). This is quite close to Jönköping (0.18), which has a low concentration of youth-choir members.

\section{Children choirs}

Children choirs are in the middle in terms of membership size, with 25,037 members in Sweden. There is a maximum of 15.13 per mille of inhabitants in Robertsfors (see Map 3 and Table 4). Out of 290 municipalities, 30 do not have any children choir members. Overall, the membership seems to be fairly evenly distributed between the types of municipalities. However, there seems to be a clustering in and around the biggest cities as the children choirs seem to be fairly evenly distributed in type A. Gothenburg (2.02) seems to stand out with a somewhat higher membership. However, especially outside the Stockholm municipality (2.18) and to a degree Malmö (1.04), type B municipalities also seem to contain quite high numbers in surrounding municipalities.

In central Sweden, the type C municipalities of Torsby (11.1) and Vansbro (8.82) stand out. In addition, further south there seems to be clustering of choirs as well besides the earlier clustering in type A municipalities. In the northern part of 
Youth choir members in the Church of

Sweden per mille (2020)
- $0-0,19$
O $0,19-0,55$
$0,55-1,10$
$1,10-1,77$
$1,77-3,57$

\section{SKR (2017) Municipality types}

Type A: Metropolitan areas and municipalities close to metropolitan areas

Type B: Larger cities and municipalities near larger cities

Type C: Smaller cities, urban areas (tätort) and rural municipalities

\section{Stockholm}

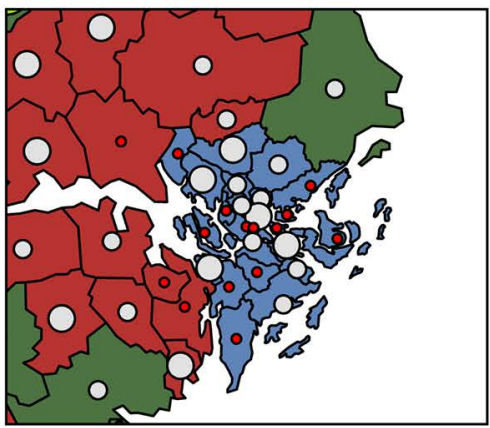

Göteborg

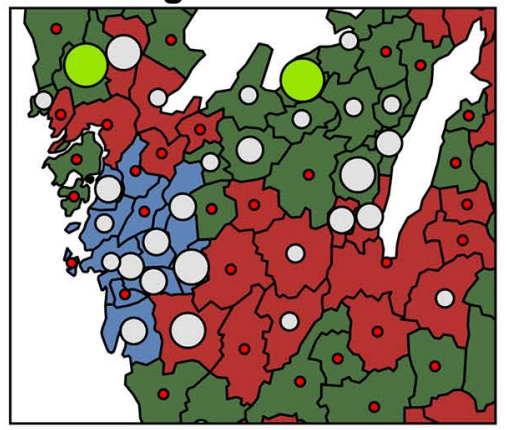

Malmö

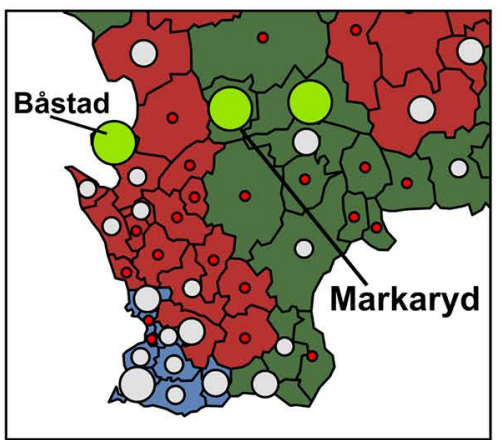

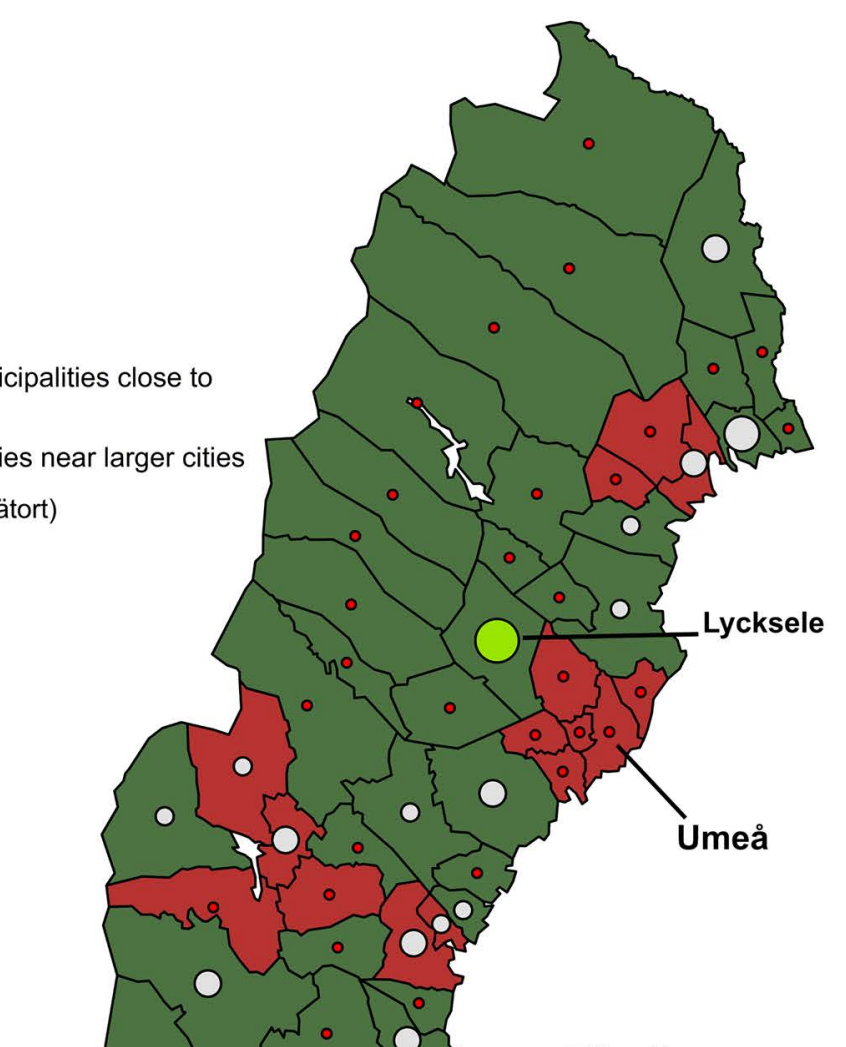

Rättvik Ockelbo Avesta

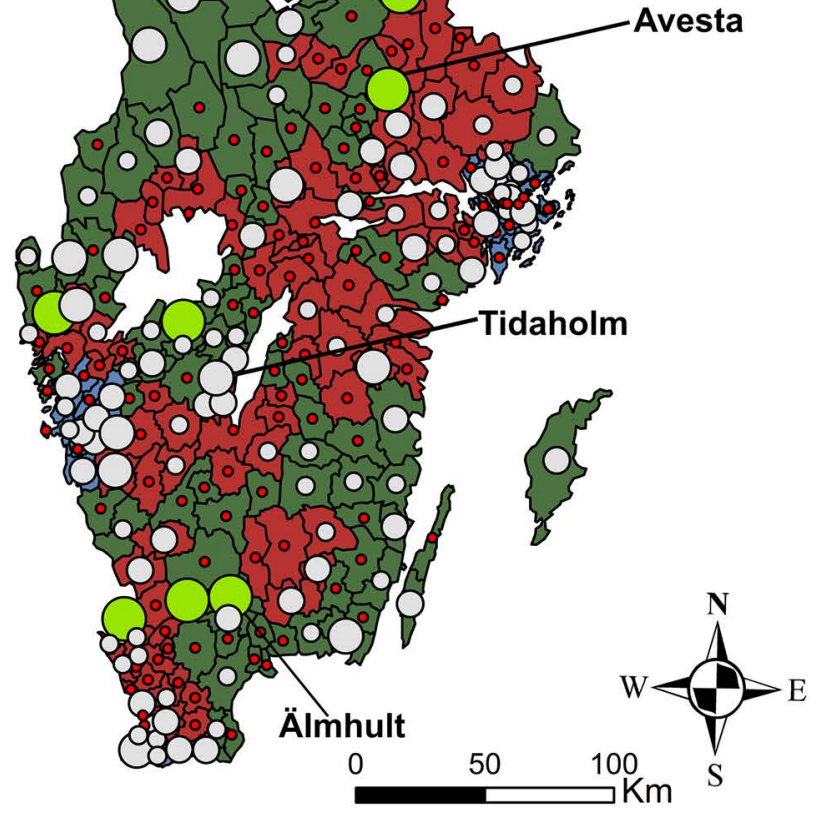

Map 2. Number of youth-choir members in the Church of Sweden per municipality. Map by the author. 
Children choir members in the Church of

Sweden per mille (2020)
- $0-0,98$
○ $0,98-2,40$
O $2,40-4,10$
$4,10-6,75$
$6,75-15,13$

SKR (2017) Municipality types

Type A: Metropolitan areas and municipalities close to metropolitan areas

$\square$ Type B: Larger cities and municipalities near larger cities Type C: Smaller cities, urban areas (tätort) and rural municipalities

\section{Stockholm}

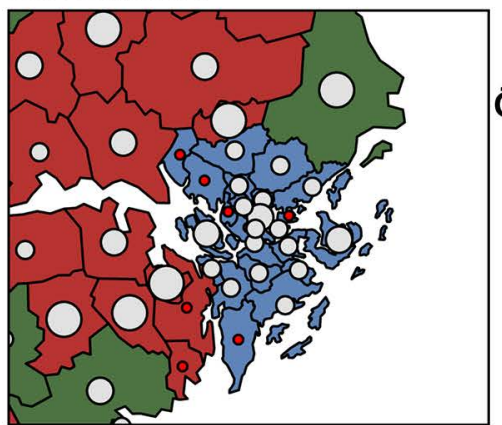

Göteborg

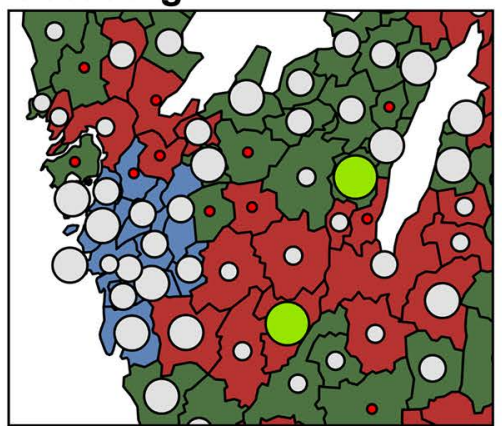

Malmö
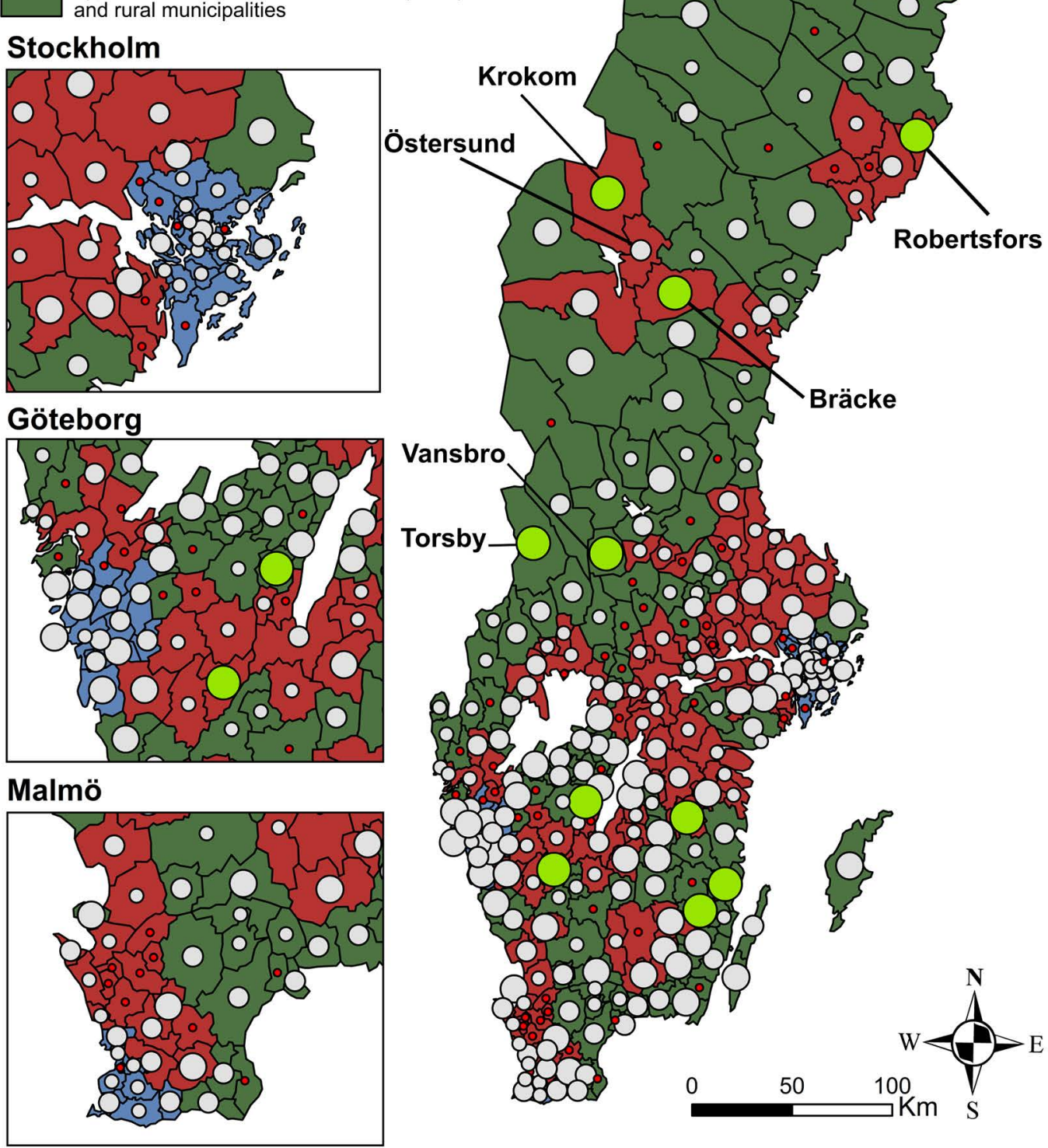

Map 3. Number of children choir members in the Church of Sweden per municipality. Map by the author. 
Sweden, choir members appear to be quite evenly dispersed. In addition, the numbers seem to decrease northwards. However, around Östersund (4.1) there seem to be many choirs of type $\mathrm{C}$ neighbouring type B municipalities of Krokom (8.03) and Bräcke (10.36). In addition, Robertsfors (15.13) sticks out along the northern coast with the largest number of children choir members. This municipality also lies next to the larger city of Umeå (3.62).

\section{Membership in the Church of Sweden}

In 2020, 55.2 per cent of the population of Sweden belonged to the Church of Sweden (Svenska kyrkan 2021a). For all municipalities, the range between the highest and lowest proportion of adherents is between 77.4 per cent in Torsby and 28.4 per cent in Botkyrka. There seem to be more municipalities that have a higher number of members in the north of Sweden (see Map 4). However, there is a slightly lower number in the northern type B municipalities, such as Umeå (61 per cent), Luleå (64 per cent) and Östersund (66 per cent). In type $C$ in the northern part of Sweden, some municipalities, such as Åre (63 per cent) and Härnösand ( 59 per cent), have lower proportions of adherents than the average for the area.

Higher membership in the Church of Sweden seems to be common for type C municipalities (see Map 4 and Table 5). In the southern half of Sweden, there also seems to be a lower number of members in the Church of Sweden. This is especially the case in the type A municipalities and in particular in Stockholm and surrounding municipalities (see Map 4 and Table 6).

\section{Discussion}

Attention is drawn towards limitations in this article and with the method of mapping quantitative data and interpreting it qualitatively. The first fundamental in

Table 5. The five municipalities sorted by the highest number of members in the Church of Sweden per mille of inhabitants and the number of choir members in 2020

\begin{tabular}{|l|l|l|l|l|l|}
\hline Municipality & Adults & Youth & Children & $\begin{array}{l}\text { Members in the } \\
\text { Ch. of Sweden }\end{array}$ & Municipality type \\
\hline Torsby & 8.50 & 1.56 & 11.10 & $77.4 \%$ & C \\
\hline Grästorp & 26.88 & 0.00 & 3.02 & $77.2 \%$ & B \\
\hline Norsjö & 15.22 & 0.00 & 3.81 & $76.7 \%$ & C \\
\hline Kalix & 4.30 & 1.27 & 4.18 & $76.6 \%$ & C \\
\hline Överkalix & 10.65 & 0.00 & 5.48 & $76.3 \%$ & C \\
\hline
\end{tabular}

Table 6. The five municipalities sorted by the lowest number of members per mille of inhabitants in the Church of Sweden and the number of choir members in 2020

\begin{tabular}{|l|l|l|l|l|l|}
\hline Municipality & Adults & Youth & Children & $\begin{array}{l}\text { Members in the } \\
\text { Ch. of Sweden }\end{array}$ & Municipality type \\
\hline Botkyrka & 3.33 & 0.00 & 1.99 & $28.4 \%$ & A \\
\hline Södertälje & 2.47 & 0.06 & 0.98 & $32.4 \%$ & B \\
\hline Malmö & 3.55 & 0.46 & 1.04 & $35.5 \%$ & A \\
\hline Sundbyberg & 3.25 & 0.17 & 0.86 & $39.1 \%$ & A \\
\hline Solna & 1.28 & 0.00 & 1.76 & $39.7 \%$ & A \\
\hline
\end{tabular}


Percentage of members in the

Church of Sweden for each municipality (2020)

- $28-47 \%$

○ $47-57 \%$

○ $57-63 \%$

○ $63-69 \%$

○ $69-77 \%$

SKR (2017) Municipality types

Type A: Metropolitan areas and municipalities close to metropolitan areas

$\square$ Type B: Larger cities and municipalities near larger cities Type C: Smaller cities, urban areas (tätort)
and rural municipalities

\section{Stockholm}

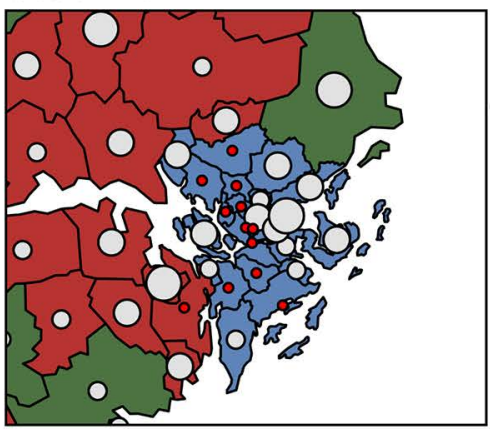

\section{Göteborg}
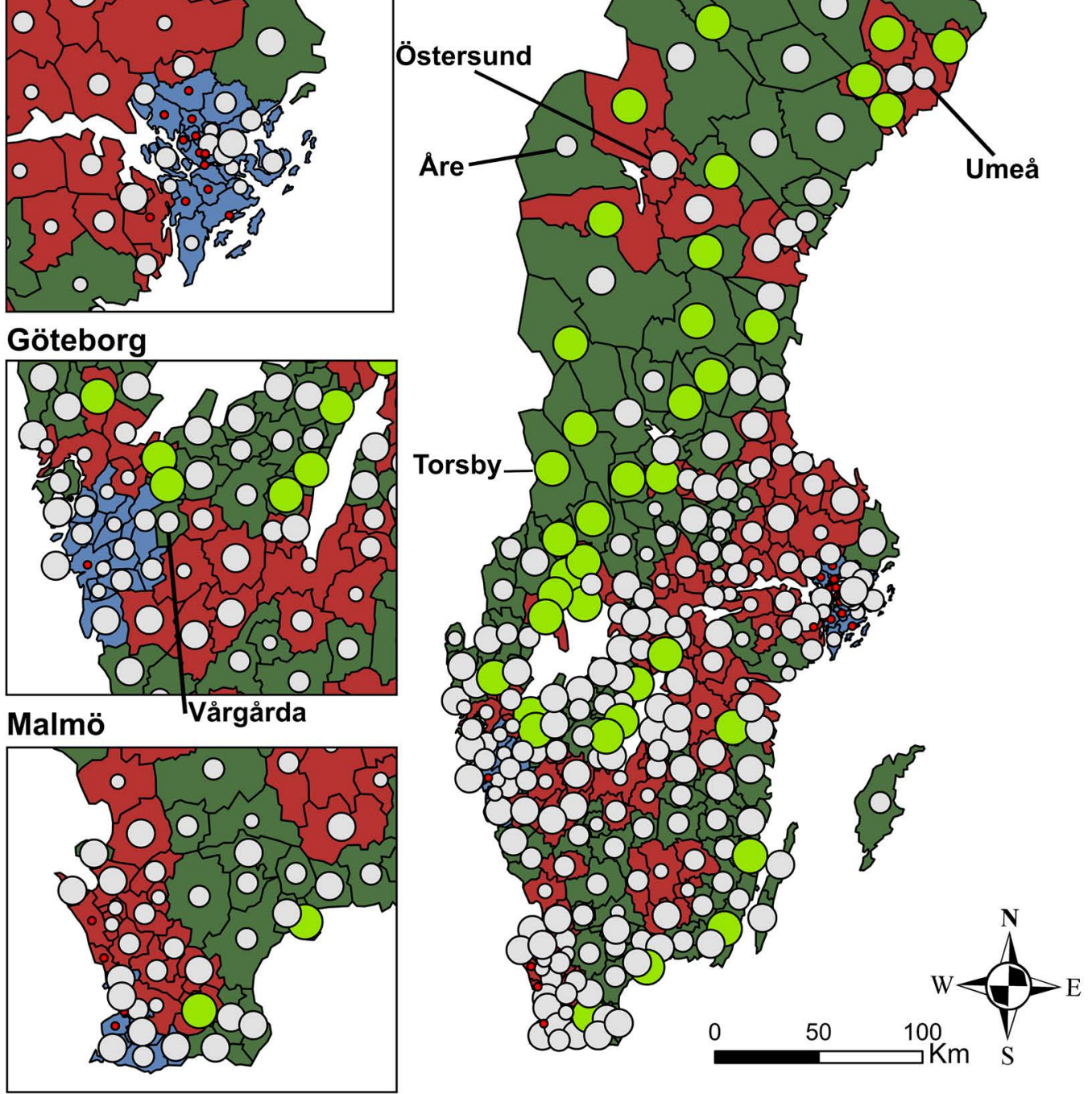

Map 4. Number of members in the Church of Sweden per municipality. Map by the author. 
reading the maps is to note that the symbols represent different numbers in each map as the dataset displays different types of data. For example, the highest number of members in adult choirs is 30.66 (Ydre) but for the youth choirs, the same number is 3.57 (Lycksele). This should be noted as it can affect the qualitative interpretation of the maps and tables produced, as the maximum number is not the same for the types of choirs. In addition to this, the method relies on qualitative interpretation of maps and data; there are no claims for casual relationships in the discussion below. The results below should instead be viewed as a first attempt to guide further studies to reveal the geographies of choirs in Sweden. This also contributes to the first observation of McCoy and Witvliet (2015), who highlight that the geographic study of choirs may reveal where worshipping communities, choirs and their members are or are not located. However, as this is the first mapping of the geography of choirs in Sweden, this article functions as a complement to both quantitative and qualitative methods and gives a first glance at the data. The second issue is the problem of municipalities in terms of a population containing large variations in SKR (2016) definition, which in turn can skew the analyses and visualization (see Table 1). This is not only due to the definition but also because in most cases urban and rural areas differ largely in both area and population. Thus, the distribution of choir members and members in the Church of Sweden can be a function of a larger population in some municipalities. This effect is mitigated somewhat by displaying the data in terms of per mille of inhabitants and percentage of the population for the Church of Sweden. However, this issue should be noted in the subsequent discussion.
With the previous discussion in mind, the maps are analysed further and reveal some interesting patterns in terms of differences between municipalities. We see that the municipalities with the highest number of adult choir members in Table 2 have almost no youth members. One interpretation of this is that the parish decides which age group is included in each category, so there could be members that should have been in another category. Another striking feature is that 129 out of 290 municipalities do not have youth-choir members. However, in Table 4 we see that the top municipalities with youth-choir members have a range between 3.38 to 15.57 for adult choir members. This raises questions of why municipalities in Table 2 have many adult choir members but almost no youthchoir as compared with Table 4. One possible explanation could be that these parishes do not uniformly classify the different choir types in the same age span. Another possibility is that the choirs do not report the membership rate. However, to delve into this issue deeper is beyond the scope of this article but could be a topic of interest in further studies.

In terms of children choir members there seems to be a cluster of many members around the type $\mathrm{C}$ municipalities of Östersund, Krokom and Bräcke. However, Table 4 reveals that three out of five are in type $\mathrm{B}$ and the rest in type $\mathrm{C}$. This seems to be the case in most other type B municipalities. However, outside Malmö, there are many type $\mathrm{B}$ municipalities with a lower number of children choir members. However, in type A municipalities around Gothenburg, there also seem to be relatively high numbers.

Map 4 shows the distribution of membership in the Church of Sweden. It appears that type $\mathrm{C}$ municipality areas tend to have a higher percentage of members. This is 
especially apparent in the northern part of Sweden, where membership of the Church is generally higher than in the south of Sweden. If we consult Table 5, the five municipalities with the highest number of members of the Church of Sweden have a range between 77.4 and 76.3 per cent. Only one out of five municipalities are type B and the rest type $\mathrm{C}$. This pattern is almost inverted for the lowest membership in the Church of Sweden in Table 6. With a range of 28.4-39.7 per cent, only one municipality is type $\mathrm{B}$, and the rest type A. There seems to be a difference emerging that type $\mathrm{C}$ municipalities have a higher degree of membership in the Church of Sweden than type A. Therefore, we can glimpse a pattern that points towards a potential spatial factor in the relationship between rural municipalities and membership in the Church of Sweden. This is in line with Kasselstrand (2015), that rural areas tend to be associated with the Church of Sweden. As location seems to matter both for the number of choir members and membership in the Church of Sweden, this reveals a potential discussion on urban and rural areas and the post-secular theory.

When juxtaposing the number of choir members in the Church of Sweden and members in the latter per municipality, some interesting results emerge. In the northern part, membership in choirs of all types is in general low, especially in type C. Examination of membership in the Church of Sweden reveals that it is generally high in these areas. This reveals that high membership in the Church of Sweden does not necessarily mean a high degree of choir membership. However, a notable example that stands out is the type C municipalities of Sorselse, Malå and Ydre. They are interesting as they have large numbers of adult choir members together with a high percentage of members in the Church of Sweden.
To reveal more insights into the geographies of choirs in Sweden further research is needed. As previously stated, Geisler and Johansson (2019) note that choirs are a complex and multifaceted field of research that requires different approaches and theoretical perspectives. In line with this, some suggestions for further studies are made, together with a theoretical discussion. This article only glimpses the distribution of choir members in the Church of Sweden, so a more rigid quantitative analysis is suggested to reveal potential covariance or casual relationship between different factors relating to choirs to determine whether the type of choir, choir organization, type of municipality or population size influence membership rate in both the Church of Sweden and its choirs. Additional datasets could also be added to the analyses, covering other choir organizations such as different adult educational associations (studieförbund) and the Swedish Choir Organization (Sveriges körförbund), to reveal whether other secular types of choirs follow the same pattern as religious ones or if they reveal other distribution patterns.

This article will end by briefly pointing out the theoretical relevance of the geographical study of choirs in Sweden. We must note that through the production of the choropleth maps with only data from the Church of Sweden, the area represented is compromised by a certain type of religious composition. Behind every number are choir singers, who have different sacred and secular worldviews. As knowledge about this area is partial, the interpretation of the maps and data should be considered as partial: there are many different religious or non-religious affiliations and viewpoints for the Swedish population, members of the Church of Sweden and choir members. Thus the use solely of membership rates in each municipality is a blunt 
tool to interpret the personal experience of choir participation. It does not account for regional cultural, musical and choir histories, which could have led to interesting place-based insights. Thus, further studies are suggested as the case of Sweden is interesting because of its steady choir participation through history, its current high number of choir members and present-day religious composition. Choir activities can be considered to be twofold: (partly) religious and (partly) secular, opening questions of (post-)secularization. Thus the investigation of the places and individuals where choir participation takes place could further our understanding of identity in urban and rural spaces in contemporary Swedish society. Questions of culture, lifestyle and the post-secular theory are central to an understanding of the geographies of choirs in Sweden.

\section{Per Göransson is a Ph.D.} student of human geography at Karlstad University. He has both BA and MA degrees in urban and regional planning (Stockholm University). His research focuses on the spatial aspects of both secular and sacral choirs

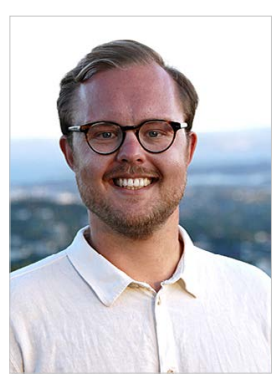
in Sweden, which is the focus of his doctoral thesis with the working title 'Choirographies: The Geographies of Choirs in Sweden'. By focusing on how participants' identities and social, cultural and economic capital interact with place, he is interested in what choirs can tell us about contemporary Sweden. In a broader sense, he is also interested in religion, non-religion and postsecular theory.

\section{References}

Arnold, Jonathan. 2019. Music and Faith: Conversations in a Post-Secular Age (Woodbridge: Boydell \& Brewer), doi: $<$ https://doi. org/10.2307/j.ctvb4bws3 $>$.

Beaumont, Justin, and Christopher Baker (eds.). 2011. Postsecular Cities: Space, Theory and Practice (London: A\&C Black), doi: $<$ https://doi.org/10.5040/9781472549198>.

Beaumont, Justin, and Klaus Eder. 2019. 'Concepts, processes and antagonism of postsecularity', in The Routledge Handbook of Postsecularity, ed. Justin Beaumont (London: Routledge), 1-24, doi: $<$ https://www.routledgehandbooks.com/ doi/10.4324/9781315307831>.

Beckford, James A. 2012. 'Public religions and the postsecular: critical reflections', Journal of the Scientific Study of Religion 51(1): 1-19.

Brunn, Stanley D., and Martin Dodge. 2017. 'What is where? The role of map representations and mapping practices in advancing scholarship', in Mapping Across Academia, eds. Stanley D. Brunn and Martin Dodge (New York: Springer), 1-22.

Chun, Yongwan. 2017. 'Spatial statistical visualization', in Encyclopedia of GIS, eds. Shashi Shekhar, Hui Xiong, and Xun Zhou (New York: Springer International Publishing), doi: <https://doi. org/10.1007/978-3-319-17885-1_1525>.

Cockayne, Daniel. 2019. 'Considering Matthew Shepard: normative and antinormative queer spatial narratives and the politics of performance in choral music', Cultural Geographies 26(4): 47185, doi: <https://journals.sagepub.com/ doi/10.1177/1474474019856409>.

Cohen, Sara. 1995. 'Sounding out the city: music and the sensuous production of place, Transactions of the Institute of British Geographers 20(4): 434-46, doi: <https:// doi.org/10.2307/622974>.

Connell, John, and Chris Gibson. 2003. Sound Tracks: Popular Music, Identity, and Place (London: Routledge), doi: <https://doi. org/10.4324/9780203448397>.

De Smith, Michael, Michael Goodchild, and Paul Longley. 2018. Geospatial Analysis (London: Winchelsea Press). 
Dodge, Martin. 2015. 'Mapping and geovisualization', in Approaches to Human Geography: Philosophies, Theories, People and Practices, eds. Stuart C. Aitken and Gillian Valentine (Thousand Oaks, CA: Sage), 289-305.

Duffy, Michelle. 2009. 'Sound and music', in The International Encyclopaedia of Human Geography, eds. R. Kitchin and Nigel Thrift (Amsterdam: Elsevier), 230-5.

Galway, Kiera Mary. 2017. Sounding Spaces: Exploring Interactions Among Space, Place, Music and Identity in a Canadian Community Choir (University of Toronto).

Gao, Quan, Junxi Qian, and Zhenjie Yuan. 2018. 'Multi-scaled secularization or postsecular present? Christianity and migrant workers in Shenzhen, China', Cultural Geographies 25(4): 553-70, doi: <https://doi. org/10.1177/1474474018762814>.

Geisler, Ursula. 2010. Choral Research. A Global Bibliography (Malmö: Körcentrum Syd).

Geisler, Ursula, and Karin Johansson. 2019. 'Contemporary concepts and practices of choral singing, in The Oxford Handbook of Singing, eds. Graham F. Welch, David M. Howard, and John Nix (Oxford University Press), 775-90, doi: <https://doi.org/10.1093/ oxfordhb/9780199660773.013.31>.

Gibson, Chris, and Andrea Gordon. 2016. 'Rural cultural resourcefulness: how community music enterprises sustain cultural vitality', Journal of Rural Studies 63(1): 259-70, doi: <https://doi.org/10.1016/j. jrurstud.2016.11.001>.

Grünhagen, Céline. 2012. 'Healing chants and singing hospitals', in Post-Secular Religious Practices, eds. Tore Ahlbäck and Björn Dahla (Turku: Donner Institute for Research in Religious and Cultural History), 76-88.

Habermas, Jürgen. 2008. 'Notes on post-secular society', New Perspectives Quarterly 25(1): 17-29, doi: <https://doi.org/10.111 $1 / \mathrm{j} .1540-5842.2008 .01017 . \mathrm{x}>$.

Håkansson, Ragnar, and Marita Sköldberg. 2020. Vi älskar att sjunga! (Visby: Wessmans musikförlag).

Haugland Balsnes, Anne. 2009. A loere i kor: Belcanto som praksisfellesskap (Oslo: Norges musikkhøgskole).

Hawn, Michael C. 2015. 'Landscapes and soundscapes: how place shapes Christian congregational song', in The Changing World
Religion Map, ed. Stanley D. Brunn (New York: Springer), 2659-77, doi: <https://doi. org/10.1007/978-94-017-9376-6>.

Hedell, Kia. 2009. 'Körsång som folkrörelse', in Signums svenska kulturhistoria: 1900talet, ed. Jakob Christensson (Stockholm: Signum).

Hentschel, Linn. 2017. Sångsituationer. En fenomenologisk studie av sång $i$ musikämnet under grundskolans senare år (Umeå University).

Hudson, Ray. 2006. 'Regions and place: music, identity, and place', Progress in Human Geography 30(5): 626-34, doi: $<$ https://journals.sagepub.com/doi/ abs/10.1177/0309132506070177>.

Jones, Rhys, and Jesse Heley. 2016. 'Post-pastoral? Rethinking religion and the reconstruction of rural space, Journal of Rural Studies 45(1): 15-23, doi: <https://doi. org/10.1016/j.jrurstud.2016.02.008>.

Joyvoice. 2021. 'Hej! Var vill du sjunga?', Joyvoice [website], <https://joyvoice.se/> (accessed 28.12.2021).

Kasselstrand, Isabella. 2015. 'Nonbelievers in the church: a study of cultural religion in Sweden', Sociology of Religion 76(3): 27594, doi: <https://doi.org/10.1093/socrel/ srvo26>.

Knigge, LaDona, and Meghan Cope. 2009. 'Grounded visualization and scale: a recursive analysis of community spaces', in Qualitative GIS: A Mixed Method Approach, eds. Meghan Cope and Sarah Elwood (Thousand Oaks, CA: Sage), doi: <https://dx.doi. org/10.4135/9780857024541.n6>.

Kong, Lily. 1995. 'Popular music in geographical analyses', Progress in Human Geography 19(2): 183-98, doi: <https://doi.org/10.117 7/030913259501900202>.

Kong, Lily. 2010. 'Global shifts, theoretical shifts: changing geographies of religion', Progress in Human Geography 34(6): 755-76, doi: <https://doi. org/10.1177/0309132510362602>.

Larsen, Lillian I. 2015. 'Mapping religiously or religiously minding the map?', in The Changing World Religion Map, ed. Stanley D. Brunn (New York: Springer), 323-47, doi: <https:// doi.org/10.1007/978-94-017-9376-6>.

Ley, David, and Justin Tse. 2013. 'Homo religiosus? Religion and immigrant subjectivities', in Religion and Place: Land- 
scape, Politics, Piety, eds. Peter Hopkins, Lily Kong, and Elisabeth Olson (New York: Springer), doi: <https://doi. org/10.1007/978-94-007-4685-5_9>.

Leyshon, Andrew, David Matless, and George Revill. 1995. 'The place of music', Transactions of the Institute of British Geographers 20(4): 423-33, doi: <https://doi. org/10.2307/622973>.

Lindström, Dorota. 2006. Sjung, sjung för livet! En studie av körsång som pedagogisk verksamhet och av deltagarnas upplevelse av hälsa och livskvalitet (Luleå University).

Lundblad, David. 2019. Svensk körklang. Historiska, fonetiska och pedagogiska aspekter (University of the Arts Helsinki).

McCoy Andrew M., and John D. Witvliet. 2015. 'Putting Christian congregational song on the geographer's map', in The Changing World Religion Map, ed. Stanley D. Brunn (New York: Springer), 2611-25.

Molendijk, Arie, Justin, Beaumont, and Christoph Jedan (eds.). 2010. Exploring the Postsecular: The Religious, the Political, the Urban (Leiden: Brill), doi: <https://doi. org/10.5040/9781472549198>.

Myndigheten för kulturanalys. 2019. Kulturens geografi. Tillgång till kulturutbud $i$ landets kommuner, Kulturfakta 2019:3, <https://kulturanalys.se/wp-content/ uploads/2020/o9/Kulturens_geografi2_ webb.pdf $>$.

O’Mahony, Eoin. 2019. 'Connecting the local and the global in post-secular urban settings', Geographical Review 109(1): 3-26, doi: <https://doi.org/10.1111/gere.12307>.

Park, Chris. 1994. Sacred Worlds. An Introduction to Geography and Religion (London: Routledge).

Pavlovskaya, Marianna. 2009. 'Non-quantitative GIS', in Qualitative GIS: A Mixed Method Approach, eds. Meghan Cope and Sarah Elwood (Thousand Oaks, CA: Sage), 13-41, doi: <https://dx.doi. org/10.4135/9780857024541.n6>.

Piece of Me AB. 2021. 'Sjung med Happy Voices vårterminen 2022', Gabriel Forss [website], $<$ https://gabrielforss.se/sjung-med-gabriel/> (accessed 28.12.2021).

Putnam, Robert D. 1993. 'What makes democracy work?', National Civic Review 82(2): 101-7, doi: <https://doi.org/10.1002/ ncr.4100820204>.
Runevad Kjellmer, Jakob. 2021. 'Körförbundet tappar medlemmar: "Olyckligt med skräckrapporterna”, SVT Nyheter 31.5.2021, $<$ https://www.svt.se/kultur/korforbundettappar-medlemmar-olyckligt-med-skrackrapporterna $>$ (accessed 28.12.2021).

SKR $=$ Sveriges Kommuner och Regioner. 2016 Kommungruppsindelning 2017. Omarbetning av Sveriges kommune och landstings kommungruppsindelning (Sveriges Kommuner och Regioner).

Smith, Susan J. 1994. 'Soundscape', Area 26(1): 232-40.

Smith, Susan J. 1997. 'Beyond geography's visible worlds: a cultural politics of music', Progress in Human Geography 21(1): 50229, doi: <https://doi.org/10.1191/03091329 $7675594415>$.

Söderberg, Kajsa. 2018. 'Kyrkokörerna bara för medlemmar?', Kyrkans Tidning 24.1.2018, <https://www.kyrkanstidning.se/nyhet/ kyrkokorerna-bara-medlemmar $>$ (accessed 28.12.2021).

Soja, Edward. 1989. Postmodern Geographies: The Reassertion of Space in Critical Social Theory (London: Verso Press).

Sparks, Richard. 2000. The Swedish Choral Miracle: Swedish A Cappella Music Since 1945 (Leeds: Blue Fire Productions).

Stenbacka Susanne, and Susanna Heldt Cassel. 2020. 'Introduktion: periferier och periferialisering', in Periferi som process, eds. Susanna Stenbacka and Susanna Heldt Cassel (Svenska Sällskapet för Antropologi och Geografi), 7-24.

Stoeckl, Kristina, and Dmitry Uzlaner. 2018. 'Four genealogies of postsecularity', in The Routledge Handbook of Postsecularity, ed. Justin Beaumont (London: Routledge), 269-79, doi: <https://www.routledgehandbooks.com/doi/10.4324/9781315307831>.

Stuart Sinton, Diana, and William A. Huber. 2007. 'Mapping polka and its ethnic heritage in the United States', Journal of Geography 106(2): 41-7, doi: <https://www.tandfonline.com/doi/ abs/10.1080/00221340701487913>.

Stump, Roger W. 2008. The Geography of Religion: Faith, Place, and Space (Lanham, MD: Rowman \& Littlefield Publishers).

Svahn, Niklas. 2020. 'Pandemin förstör för Sveriges körsångare', Svenska Dagbladet 26.7.2020, <https://www.svd.se/ 
lang-tid-innan-korsang-kan-genomforasnormalt $>$ (accessed 31.8.2021).

Svenska kyrkan. 2021a. 'Svenska kyrkan i siffror', Svenska kyrkan [website], <https:// www.svenskakyrkan.se/statistik> (accessed 28.12.2021).

Svenska kyrkan. 2021b. 'Vanliga frågor om medlemskap', Svenska kyrkan [website], $<$ https://www.svenskakyrkan.se/farsta/ fragormedlemskap $>$ (accessed 28.12.2021).

Taylor, Charles. 2007. The Secular Age (Cambridge, MA: Harvard University Press).

Theorell, Töres. 2009. Noter om musik och hälsa (Stockholm: Carlsson).

Tweed, Fiona, and Allan Watson. 2018. 'The screams all sound the same: the music of monsters and men and the Icelandic imaginary as geographical discourse', Area 51(1): 126-33, doi: <https://doi.org/10.1111/ area.12422>.

Warf, Barney, and Santa A. Arias (eds.). 2008. The Spatial Turn: Interdisciplinary Perspectives (London: Routledge).

Waterman, Stanley. 2006. 'Geography and music: some introductory remarks', GeoJournal 65: 1-2. 